\section{POSTOJI LI RAZLIKA U PROCJENI KVALITETE ŽIVOTA IZMEĐU RODITELJA DJECE S TEŠKOĆAMA U RAZVOJU I RODITELJA DJECE BEZ TEŠKOĆA U RAZVOJU: METAANALIZA ${ }^{3}$}

Izvorni znanstveni članak

Primljeno: siječanj, 2017.

Prihvaćeno: listopad, 2018.

UDK 316.728-055.52

DOI 10.3935/ljsr.v25i2.153

Aleksandra

Bogdanović ${ }^{1}$

orcid.org/0000-0001-6710-3248

Miljana Spasić

Šnele ${ }^{2}$

orcid.org/0000-0001-5492-3386

Univerzitet u Nišu

Filozofski fakultet

\section{SAŽETAK}

Ovo metaanalitičko istraživanje provedeno je s ciljem integriranja nalaza dobivenih u pojedinačnim istraživanjima koja su se bavila ispitivanjem razlika u subjektivnoj procjeni kvalitete života između roditelja djece s teškoćama u razvoju i roditelja djece bez teškoća u razvoju, odnosno opće populacije. Metaanaliza je provedena na uzorku od 14 pojedinačnih istraživanja i sadržavala je 2088 ispitanika iz grupe roditelja djece s teškoćama u razvoju, 783 ispitanika roditelja djece bez teškoća u razvoju u sedam istraživanja, dok su se u preostalih

1 Aleksandra Bogdanović, psihologinja, e-mail: aleksandra.bogdanovic@filfak.ni.ac.rs

Miljana Spasić Šnele, psihologinja, e-mail: miljanaspasic@ymail.com

3 Rad je nastao u sklopu projekta »Indikatori i modeli usklađivanja porodičnih i poslovnih uloga«, br. 179002, koji financira Ministarstvo prosvete, nauke i tehnološkog razvoja Republike Srbije.
Ključne riječi:

kvaliteta života, roditelji, roditelji djece s teškoćama u razvoju. 
sedam istraživanja za usporedbu koristile norme izgrađene na osnovi rezultata populacije bez invaliditeta za dano geografsko područje. Vrijednost standardizirane razlike između aritmetičkih sredina je $d=-0,24$ i pokazuje nam da postoji statistički značajna razlika, male veličine, između roditelja djece s teškoćama u razvoju i roditelja djece bez teškoća u razvoju, odnosno populacije bez invaliditeta, u pogledu subjektivne procjene kvalitete života $(z=-2,06, p<0,05)$, pri čemu je lošija kvaliteta života roditelja djece s teškoćama u razvoju. Pokazalo se da unutar grupe roditelja djece s teškoćama u razvoju ne postoji razlika u subjektivnoj procjeni kvalitete života između majki i očeva.

Rezultati ovog istraživanja ukazuju na postojanje potrebe za razvojem boljih $i$ specifičnijih intervencija namijenjenih pomoći i podršci ovoj grupi korisnika, ali treba imati u vidu ograničenja proizašla iz metodologije ovog rada, te se budućim istraživačima upućuje preporuka da isprave nedostatke ovog istraživanja kako bi se unaprijedile kvaliteta i valjanost nalaza.

\section{UVOD}

Kvaliteta života je koncept kojim se znanstvena javnost, posebno iz područja psihologije, filozofije, sociologije i medicine, počela baviti 70-ih godina dvadesetog stoljeća. Od tada je objavljeno nekoliko milijuna znanstvenih publikacija u kojima se spominje kvaliteta života, dano preko sto definicija ovog koncepta (Schalock, 2004.) i razvijeno čak 1275 različitih instrumenata za njegovu procjenu (llić, Milić i Aranđelović, 2010.). Jedna od najcitiranijih je definicija grupe autora okupljenih oko teme kvalitete života pod okriljem Svjetske zdravstvene organizacije, po kojoj se kvaliteta života određuje kao osobna percepcija vlastitog načina života u kontekstu kulture, sustava vrijednosti, težnji, izgleda za budućnost, standarda i interesa (Whoqol Group, 1998.). Autori Krizmanić i Kolesarić (1989.) kvalitetu života definiraju kao subjektivno doživljavanje vlastitog života određeno objektivnim okolnostima u kojima osoba živi, karakteristikama osobnosti koje utječu na to kako će se doživjeti realnost i specifičnog životnog iskustva osobe. Preduvjeti za kvalitetan život su puno i aktivno sudjelovanje u interakcijskim i komunikacijskim procesima, kao i razmjena u okviru fizičkog i društvenog okruženja (Krizmanić i Kolesarić, 1989.). Objektivne mjere, kao što je procjena socio-ekonomskog statusa, nisu dovoljne za objašnjenje kvalitete života. Cummins (2000.) navodi da stvarno poboljšanje uvjeta života, kada su ti uvjeti bili jako loši, dovodi i do poboljšanja subjektivne procjene kvalitete života, ali se na određenoj razini ta povezanost gubi. Drugim riječima, ako su zadovoljene osnovne potrebe pojedinca, povećanje materijalnih dobara neće značajno utjecati na subjektivnu mjeru kvalitete života.

Vanjski faktori mogu imati značajnu ulogu u objašnjavanju općeg zadovoljstva i kvalitete života, ali povezanost ovih faktora i doživljaja kvalitete života nije linearna. Važno je u obzir uzeti prirodu i intenzitet vanjskog utjecaja, pa se tako 


\section{A. Bogdanović, M. Spasić Šnele: Postoji li razlika u procjeni kvalitete života između roditelja djece...}

bolest, vlastita ili člana obitelji, smatra jednim od faktora koji mogu ostaviti najveći negativan utjecaj na život pojedinca. Posljednjih godina porasla je zabrinutost za kvalitetu života roditelja djece s teškoćama u razvoju (Vasilopoulou i Nisbet, 2016.). Opće sazrijevanje djece s teškoćama u razvoju je usporeno, a sposobnosti za učenje i prilagođavanje zahtjevima društvenog života oštećene, pa trebaju stalnu zaštitu i njegu (van Zelst i sur., 2006.), kao i odgoj i obrazovanje pod posebnim uvjetima (Eraković, 1995., prema Stojilković, 2013.). Roditelji i ostali članovi obitelji moraju svoj dnevni režim prilagoditi njihovim potrebama, te uobičajeno radno vrijeme roditelja ili barem jednoga od njih, postaje neprihvatljivo (Dulčić, 2001.). Nerijetko se događa da se majke u potpunosti odriču profesionalne karijere kako bi se mogle brinuti o djetetu s teškoćama u razvoju (Terzić, 1995., prema Stojilković, 2013.). Osim toga, potrebe osoba s invaliditetom zahtijevaju povećane novčane izdatke. Objektivne poteškoće djece i objektivno teži uvjeti obiteljskog života narušavaju obiteljsku homeostazu i mijenjaju obiteljsku dinamiku (Dulčić, 2001.). Istraživanja pokazuju da populaciju roditelja djece s teškoćama u razvoju karakterizira pojačan stres (Blacher, 1984.; Schieve i sur., 2007.; Silva i Schalock, 2012.), pogoršano mentalno zdravlje (Weiss, 1991.), osjećaj krivnje (Holroyd i sur., 1975.), poremećeno fizičko funkcioniranje, umor i iscrpljenost (Anneren i Wikblad, 2000.; Emerson, 2003.; Hedov; Tsuno, Besset i Ritchie, 2005.). Narušena je obiteljska koherentnost i prisutna socijalna izolacija (Leutar i Rajić, 2002.).

Jedan broj nedavnih istraživanja usmjeren je na istraživanje korelata subjektivne procjene kvalitete života roditelja djece s teškoćama u razvoju i na usporedbu ove grupe roditelja s roditeljima djece bez teškoća u razvoju. Nalazi tih istraživanja uglavnom pokazuju da je kvaliteta života roditelja djece s teškoćama u razvoju narušena i u korelaciji s depresivnim raspoloženjima (Sarajlija, Đurić i Kisić-Tepavčević, 2013.), roditeljskim distresom (Dardas i Ahmad, 2014.; Tung i sur., 2014.), nedostatkom traženja socijalne podrške i primjenom izbjegavanja kao strategije prevladavanja stresa (Dardas i Ahmad, 2014.), kao i s učestalim bihevioralnim smetnjama kod djece. Nadalje, u pojedinim istraživanjima razmatrano je pitanje postoje li razlike u procjeni kvalitete života majki i očeva djece s teškoćama u razvoju. Dok se u istraživanju Mugna i sur. (2007.) pokazalo da majke imaju nižu kvaliteta života od očeva, razlika nije utvrđena u istraživanju Dardasa i Ahmada (2014.). lako se rezultati određenog broja dosadašnjih pojedinačnih studija slažu u pogledu toga da je kvaliteta života roditelja djece s teškoćama u razvoju narušena, kada se oni usporede s roditeljima djece bez teškoća (Leung i Li-Tsang, 2003.; Mugno i sur., 2007.; Suzumura, 2015.), velik broj istraživanja zapravo ne uspoređuje ove dvije grupe roditelja, već ispituju samo roditelje djece s teškoćama u razvoju te, u okviru deskriptivnih nalaza, iznose vrijednosti njihove subjektivne procjene kvalitete života, ostavljajući čitatelju da dane vrijednosti usporedi s normama za opću populaciju. 
Pregledom literature, može se uočiti da sustavnog, metaanalitičkog, proučavanja razlika, izuzev za roditelje djece s autizmom (Vasilopoulou i Nisbet, 2016.), nije bilo. Mi smo se odlučili za postupak metaanalize smatrajući da je pouzdanost zaključaka u ovom području vrlo važna. Kako velika količina objavljenih radova često sadrži nepotpune, kontradiktorne ili neusuglašene zaključke, smatrali smo da njihovo sumiranje kroz postupak kombiniranja pojedinačnih rezultata istraživanja koja se bave srodnim istraživačkim hipotezama u jedinstvenu mjeru može biti koristan istraživački doprinos. Imajući to u vidu, ovo istraživanje nastalo je u pokušaju da integrira nalaze različitih istraživanja koja su se bavila pitanjem kvalitete života roditelja djece s teškoćama u razvoju i odgovori na pitanje o tome postoji li i kolika je razlika u subjektivnoj procjeni kvalitete života između njih i roditelja djece bez teškoća u razvoju, odnosno populacije bez invaliditeta. Odgovor na ovo pitanje može biti važan, posebno za stručnjake koji se bave zaštitom mentalnog zdravlja roditelja i socijalnom zaštitom djeteta, imajući u vidu da je kvaliteta života dobar indikator spremnosti roditelja da odgovore na izazove roditeljstva, kao što su pružanje njege i pomoći bolesnom djetetu (Mugno i sur., 2007., prema Tung i sur., 2014.) i da ima direktne implikacije na poboljšanje odnosa djeteta i roditelja i kvalitete njihove interakcije (Beach i sur., 2005.). Tako bi poboljšanje kvalitete života roditelja mogao biti jedan od glavnih ciljeva intervencija namijenjenih obiteljima djece s teškoćama u razvoju.

\section{METODA}

\section{Cilj istraživanja}

Cilj rada je integriranje rezultata dobivenih pojedinačnim istraživanjima o postojanju razlike u subjektivnoj procjeni kvalitete života između roditelja djece s teškoćama u razvoju i roditelja djece bez teškoća u razvoju, odnosno populacije bez invaliditeta. Dodatno, zanimalo nas je postoji li unutar grupe roditelja djece $s$ teškoćama u razvoju razlika u subjektivnoj procjeni kvalitete života između majki i očeva, te je još jedan cilj istraživanja integracija tih rezultata.

U metaanalizu je uključeno 14 istraživanja, kojima je obuhvaćeno 2088 roditelja djece s teškoćama i 7 istraživanja, kojima je obuhvaćeno 783 roditelja djece opće populacije. U tabličnom prikazu (Tablica 1.) predstavljena su uključena istraživanja, zemlje podrijetla, autori, istraživanja i kontrolna populacija te rezultati prikazani kao aritmetičke sredine i standardne devijacije na upitnicima »WHOQOL-BREF« $\mathrm{i}$ »SF36«.

\section{2 članci}




\section{Operacionalizacija varijabli}

Subjektivna procjena kvalitete života u ovom istraživanju operacionalizira se postignutim rezultatom na upitnicima »WHOQOL-100«, »WHOQOL BREEF (Whoqol Group, 1998.) i »SF-36« (Ware, Kosinski i Gandek, 2000.), koji su i najčešće korišteni instrumenti za procjenu kvalitete života u posljednje vrijeme. Zajedničko za ove upitnike je da kvalitetu života vide kao multidimenzionalni konstrukt. Dimenzije koje mjere nominalno se razlikuju, ali su svi upitnici usmjereni na procjenu fizičkog $\mathrm{i}$ mentalnog zdravlja i socijalnog funkcioniranja, pri čemu »WHOQOL-100«i »WHOQOL BREEF« imaju nešto širi fokus. Instrumenti su standardizirani za upotrebu u različitim kulturama i zemljama s različitim stupnjem ekonomskog razvoja. Čestice su kod oba instrumenta kodirane tako da viši rezultati ukazuju na višu kvalitetu života. Kod upitnika »WHOQOL« $\mathrm{i}$ »WHOQOL BREEF« moguće je izračunati pojedinačne rezultate na dimenzijama fizičko zdravlje, psihološko zdravlje, socijalni odnosi i okruženje, kao i ukupni rezultat kvalitete života, čije smo mjere koristili u ovom radu. Upitnik »SF-36« može se promatrati kroz osam pojedinačnih dimenzija: tjelesno funkcioniranje, ograničenost aktivnosti zbog fizičkih problema, tjelesna bol, opće zdravlje, vitalnost, socijalno funkcioniranje, ograničenost aktivnosti zbog emotivnih problema, mentalno zdravlje; i/ili svođenjem na dvije kompozitne dimenzije: fizičko zdravlje i mentalno zdravlje. Pored toga, kombiniranjem rezultata s dvije kompozitne dimenzije može se dobiti i jedan ukupni rezultat (Sarajlija, Đurić i Kisić-Tepavčević, 2013.). S obzirom na to da su u pitanju dva instrumenta čije subdimenzije predstavljaju indikatore (mjere) različitih aspekata kvaliteta života, odlučili smo da za potrebe ove analize koristimo ukupni rezultat, odnosno rezultat procjene kvaliteta života generalno. Teškoćama u razvoju smatramo pervazivne razvojne poremećaje (autizam, Rettov sindrom, dječji dezintegrativni poremećaj, Aspergerov sindrom i nespecifični pervazivni razvojni poremećaj), intelektualne teškoće i cerebralnu paralizu, kao tri najučestalija oblika razvojnih teškoća (Center for Disease Control and Prevention, 2010., prema Dardas i Ahmad, 2014.). U uzorak su ušli roditelji djece mlađe od 18 godina kojoj je od strane stručnjaka postavljena dijagnoza nekog od navedenih stanja na osnovi klasifikacijskih sustava DSM IV ili ICD - 10.

\section{Kriteriji za uključivanje istraživanja}

U postupak metaanalize uključena su kvantitativna istraživanja koja su zadovoljila sljedeće kriterije:

- Ispituju kvalitetu života roditelja djece s teškoćama u razvoju koristeći jedan od prethodno definiranih instrumenata.

- Teškoće u razvoju operacionalizirane su na prethodno definiran način. 
- Kvaliteta života roditelja djece s teškoćama u razvoju uspoređuje se s kontrolnom grupom ili populacijom bez invaliditeta, ili se daju podaci na osnovi kojih se to može učiniti.

- Istraživanja prikazana u znanstvenim časopisima svih kategorija (izuzev preglednih radova) u posljednjih 20 godina.

- Istraživanja na engleskom, srpskom, hrvatskom ili bosanskom jeziku.

\section{Način prikupljanja podataka}

Pretraga literature započeta je u lipnju 2016. godine, pretragom preko »Google« i "Google Scholar« pretraživača, a onda nastavljena, koristeći KoBSON platformu, preko servisa za pretragu elektronskih znanstvenih časopisa »Medline/PubMed«, "Science Direct«, »Ebsco« i »Wiley online library« i završena u lipnju 2018. pretragom servisa »Ceon« i »HrcakSrce«, sa srpsko-hrvatsko-bosanskog govornog područja. Pretraga je ograničena na znanstvene časopise objavljene u razdoblju od 1996. do 2018. godine i vršena preko kriterija koji je sadržavao sljedeće ključne riječi: (»quality of life (or QOL) + parents (mother or father or caregiver) + children with developmental disabilities or pervasive developmental disorder or autism or ASD, or cerebral palsy or intellectual disabilities«), odnosno »kvaliteta života + roditelji (otac ili majka ili staratelj) + djeca s razvojnim teškoćama (ili pervazivnim razvojnim poremećajima ili autizmom ili cerebralnom paralizom ili intelektualnim teškoćama)«. Ključne riječi i njihove kombinacije unošene su u skladu sa zahtjevima svakog servisa i poštujući gramatička i sintaktičko-leksička pravila jezika koji se koristi za pretragu. Ovakva pretraga otkrila je 186 istraživanja koja su potencijalno bila u skladu s temom metaanalize, međutim nakon pregleda naslova i ključnih riječi ustanovljeno je da je skoro polovica (98) ovih istraživanja irelevantna za ono što nas zanima (teorijski radovi, priručnici za roditelje, evaluacijska istraživanja itd.), da se 31 istraživanje zapravo ne bavi ispitivanjem kvalitete života roditelja već osoba s intelektualnim teškoćama i da je 27 istraživanja nedostupno za čitanje zbog politike ograničenog pristupa. Ostala su 24 istraživanja čijem je detaljnijem pregledu i popisu pristupljeno. Izrađena je matrica u koju su za svaki rad uneseni sljedeći podaci: naziv članka, autori, časopis u kojem je objavljen, godina objavljivanja, podaci o uzorku - odvojeno za ciljanu i usporednu grupu - tko su ispitanici, s kojeg geografskog područja, koliko ih je i je li kontrolna grupa bila prisutna u samom istraživanju ili se usporedba vrši s populacijom bez invaliditeta, zatim, vrsta mjere veličine učinka koja je korištena ili mjere iz koje se mogu dobiti podaci o veličini učinka (t-test ili aritmetička sredina i standardna devijacija za obje grupe) i veličina te mjere. Iz daljnjeg postupka uklonjeno je 13 istraživanja jer nisu bila u skladu s postavljenim kriterija. Od preostalih radova $(k=11)$ jedan je obuhvaćao tri relevantna uzorka (analiza je rađena odvojeno

\section{4 članci}




\section{A. Bogdanović, M. Spasić Šnele: Postoji li razlika u procjeni kvalitete života između roditelja djece...}

za roditelje djece s autizmom, intelektualnim teškoćama i cerebralnom paralizom), te su ovi uzorci uneseni kao zasebne jedinice analize (+2). Na kraju je za postupak metaanalize preostalo 13 istraživanja (Tablica 1.) s ukupno 1990 ispitanika iz grupe roditelja djece s teškoćama u razvoju. Šest istraživanja imalo je kontrolnu grupu sastavljenu od roditelja djece uobičajenog razvoja kojih je ukupno, u svih šest istraživanja, bilo 679 , dok su se u preostalim istraživanjima za usporedbu koristile norme izgrađene na osnovi rezultata opće populacije za dano geografsko područje.

\section{Opis istraživanja koja su uključena u postupak metaanalize}

U istraživanju Mugna i sur. (2007.) kvaliteta života je procjenjivana upitnikom »WHOQOL-BREF«kod ukupno212 roditelja (115 majkei97 očeva) stotridesetpeterodjece s dijagnozama pervazivnog razvojnog poremećaja (69), intelektualnih teškoća (89) i cerebralne paralize (54) i 77 roditelja (42 majke i 35 očeva) četrdeset osmero djece bez razvojnih teškoća. Rezultati su pokazali da je subjektivna procjena, kako ukupne percepcije kvalitete života, tako i svih pojedinačnih dimenzija kvaliteta života statistički značajno niža kod sve tri grupe roditelja djece s teškoćama u razvoju u odnosu na roditelje školske djece bez teškoća u razvoju, pri čemu su posebno ugroženi, kako autori navode, roditelji djece s pervazivnim razvojnim poremećajima. Očevi i majke djece s pervazivnim razvojnim poremećajima procjenjuju nisku ukupnu kvalitetu života, mentalno zdravlje i socijalne odnose, a majke i fizičko zdravlje. Tendencija da se postižu niži rezultati u odnosu na kontrolnu grupu postoji i u druge dvije grupe roditelja djece s teškoćama u razvoju, ali ona ne prelazi razinu statističke značajnosti. Također, majke u sve tri grupe postižu niže rezultate od očeva, što razinu statističke značajnosti dostiže za područje fizičkog zdravlja u grupi roditelja djece s pervazivnim razvojnim poremećajima i područje mentalnog zdravlja u grupi roditelja djece s cerebralnom paralizom.

U istraživanju Geoka, Abdullah i Kee (2013.) korišten je također upitnik Svjetske zdravstvene organizacije kako bi se ispitala kvaliteta života među majkama djece koja imaju dijagnozu sindrom Down. U uzorku je bila 161 ispitanica. One su ukupnu kvalitetu života procijenile srednjim vrijednostima, koje su približne normativnim vrijednostima populacije bez invaliditeta. Kada su u pitanju pojedinačne dimenzije, najniže je ocijenjeno zadovoljstvo socijalnim odnosima.

Guillamón i sur. (2013.) su provjeravali kvalitetu života (»WHOQOL-BREF«) skrbnika djece s cerebralnom paralizom, koji su bili članovi različitih organizacija udruženja osoba s ovom dijagnozom u Španjolskoj. Od šezdeset dvoje skrbnika, većina ih je ženskog spola (88\%). Rezultati su pokazali da je kvaliteta života roditelja djece s cerebralnom paralizom niža u odnosu na populaciju bez invaliditeta, pri čemu su najugroženija područja mentalno zdravlje i socijalne interakcije. 
Lin i sur. (2009.) su kvalitetu života i faktore koji joj doprinose ispitivali kod skrbnika djece s intelektualnim teškoćama koja su učenici tri posebne odgojno-obrazovne ustanove na Tajvanu, koristeći također upitnik Svjetske zdravstvene organizacije. Uzorak je činilo 597 skrbnika (uglavnom roditelja) djece s intelektualnim teškoćama (72\% ženskog spola), koje autori uspoređuju s populacijom bez invaliditeta, ali i sa skrbnicima odraslih osoba s intelektualnim teškoćama. $U$ odnosu na populaciju bez invaliditeta skrbnici djece s intelektualnim teškoćama postižu niže, ali u odnosu na skrbnike odraslih s intelektualnim teškoćama, blago više rezultate na ukupnoj kvaliteti života i na svim dimenzijama. Najniži su rezultati na području mentalnog zdravlja. Još jedno istraživanje s ovog podneblja proveli su Tung i sur. (2014.). Primjenom instrumenta »WHOQOL-BRIEF« utvrđeno je da roditelji djece s autizmom $(\mathrm{N}=82)$ kvalitetu života procjenjuje kao lošiju u odnosu na opću populaciju u svim područjima.

$\mathrm{U}$ dva istraživanja provedena u Japanu korišten je upitnik »SF-36«. U prvom istraživanju Suzumura (2015.) uspoređuje kvalitetu života majki tridesetero predškolske djece s visokofunkcionirajućim autizmom, praćene od strane dječje psihijatrijske klinike u Tokyju, s kvalitetom života majki tridesetero zdrave djece. Rezultati su pokazali da majke djece s visokofunkcionirajućim autizmom postižu statistički značajno niže rezultate na dimenzijama općeg zdravlja, vitalnosti i socijalnog funkcioniranja, a kada su u pitanju kompozitne dimenzije, na mentalnom, ali ne i na fizičkom zdravlju. Drugo istraživanje u Japanu (Yamada i sur., 2012.) provedeno je na uzorku od 269 roditelja (147 majki i 122 očeva) 158-ero djece s pervazivnim razvojnim poremećajima, koristeći, također, upitnik »SF-36«. U odnosu na opću populaciju roditelji djece s pervazivnim razvojnim poremećajima postigli su niže rezultate na obje kompozitne dimenzije kvalitete života, što ne prelazi granicu statističke značajnosti. Međutim, ako se odvojeno promatraju majke, njihova kvaliteta života, posebno u područjima koja se tiču mentalnog zdravlja je statistički značajno lošija.

U uzorak ovog metaanalitičkog istraživanja uključena su i dva istraživanja provedena u Kini. Prvo (Leung i Li-Tsang, 2003.) uspoređuje kvalitetu života (»WHO$\mathrm{QOL}$ «) roditelja djece s teškoćama u razvoju (intelektualne teškoće, sindrom Down, cerebralna paraliza) ( $N=71$, od čega $77 \%$ uzorka čine majke) i roditelja djece bez teškoća u razvoju ( $\mathrm{N}=76)$. Ove dvije grupe roditelja ne razlikuju se kada su u pitanju mentalno i fizičko zdravlje, ali statistički značajne razlike postoje kada su u pitanju socijalni odnosi i okruženje. U drugom kineskom istraživanju (Ji i sur., 2014.) autori su za cilj imali identificiranje prediktora kvalitete života (»SF-36«) kod skrbnika djece s poremećajima iz autističnog spektra ( $N=273$, odabranih pomoću 15 centara za autizam), te nije bilo usporedne grupe. Deskriptivna analiza pokazuje da je mentalno zdravlje skrbnika ugroženo područje kvalitete života.

Istraživanje Dardasa i Ahmada (2014.) spada među rijetka istraživanja koja su kvalitetu života roditelja djece s autizmom proučavala posebno za očeve $(N=70)$

\section{6 članci}


i majke ( $N$ = 114). Cilj istraživanja bio je usporedba kvalitete života očeva i majki i proučavanje uloge dimenzija roditeljski stres (PD), disfunkcionalne interakcije roditelj-dijete (PCDI) i teško dijete (DC), kao i varijabli prihod obitelji, uzrast djeteta s autizmom i broj djece u obitelji u predviđanju njihove kvalitete života. Pokazalo se da je kvaliteta života relativno niska kada je u pitanju dimenzija okruženje, i granične vrijednosti kada je u pitanju dimenzija psihičko zdravlje. Razlika u kvaliteti života među očevima i majkama djece s autizmom nije statistički značajna, što nije očekivano s obzirom na rezultate ranijih istraživanja (Mugno i sur., 2007.; Yamada i sur., 2012.).

Autori Sarajlija, Đurić i Tepavčević (2013.) istražuju kvalitetu života (»SF-36«) i depresivnost kod 49 majki djece s Rettovim sindromom. Mentalno zdravlje je najniže ocijenjena dimenzija kvalitete života, a sve dimenzije, kao i kompozitni rezultat kvalitete života negativno su povezane s depresivnošću majke i težinom simptoma prisutnih kod djeteta. Autori zaključuju da su majke djece s Rettovim sindromom visoko rizična populacija za nisku kvalitetu života i razvoj depresivne simptomatologije.

Autorice Pisula i Porębowicz-Dörsmann (2017.) su ispitivale kvalitetu života roditelja djece s visokofunckionirajućim autizmom (49 dijada majka-otac) i roditelja djece bez dijagnoze (52 dijade majka-otac) primjenom upitnika »WHOQOL-BREF«. Dobiveni nalazi ukazuju da je kvaliteta života roditelja djece s autizmom značajno niža. Najniže vrijednosti kvalitete života dobivene su u okviru područja psihološkog zdravlja i socijalnih odnosa. Nisu pronađene razlike u kvaliteti života između majki i očeva ni u jednoj grupi. 


\begin{tabular}{|c|c|c|c|c|c|c|c|}
\hline $\begin{array}{l}\text { Ỹ } \\
\text { N } \\
\stackrel{N}{\Sigma} \\
\stackrel{0}{\Sigma}\end{array}$ & 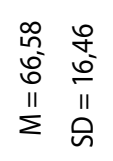 & 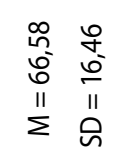 & 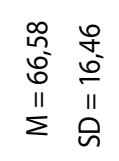 & $\begin{array}{ll}0 & 0 \\
\text { ñ } & 0 \\
\text { ñ⿱ } & 0 \\
\text { II } & 11 \\
\sum & 0\end{array}$ & 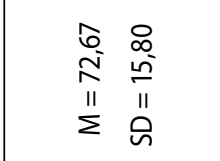 & 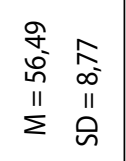 & 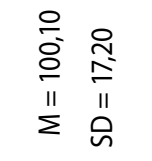 \\
\hline 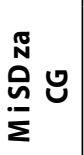 & 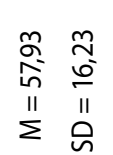 & 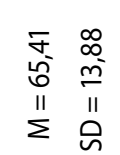 & $\begin{array}{ll}\frac{n}{n} & \bar{n} \\
\text { ñn } & \infty \\
\text { II } & 11 \\
\sum & 0\end{array}$ & \begin{tabular}{ll}
8 & \multicolumn{1}{c}{} \\
0 & $\sqrt{n}$ \\
$\mathfrak{n}^{2}$ & $\infty$ \\
II & II \\
2 & 0
\end{tabular} & 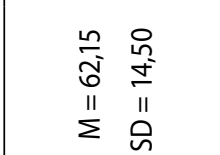 & $\begin{array}{ll}\underset{n}{n} & \kappa \\
i n & \sigma \\
\text { II } & 11 \\
\Sigma & 0\end{array}$ & 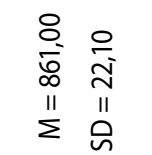 \\
\hline 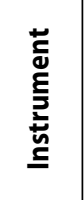 & 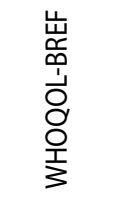 & 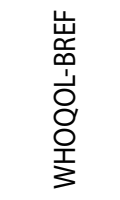 & 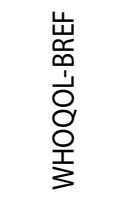 & 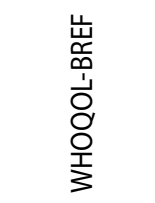 & 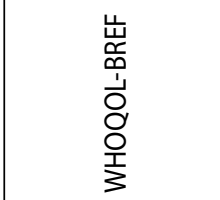 & 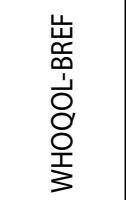 & $\begin{array}{c}0 \\
m \\
1 \\
1 \\
\sim\end{array}$ \\
\hline 疍 & 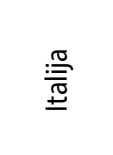 & 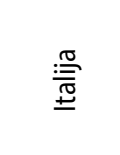 & 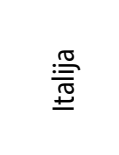 & $\frac{: \frac{\pi}{\sqrt{\overparen{V}}}}{\sum^{\frac{\pi}{2}}}$ & 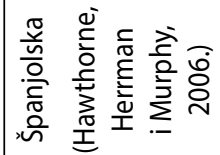 & 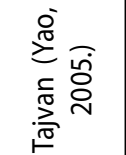 & 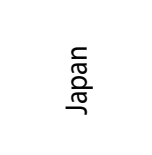 \\
\hline$z$ & 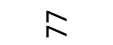 & 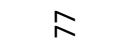 & $\hat{\wedge}$ & ৪ & กิ & 음 & 이 \\
\hline 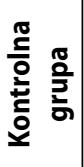 & 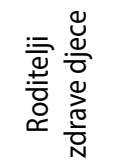 & 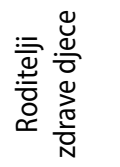 & 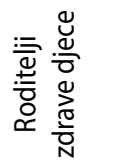 & 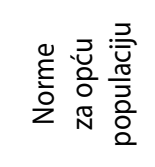 & 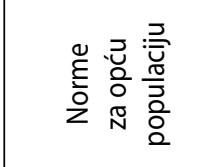 & 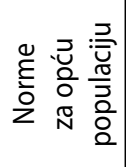 & 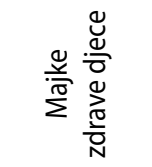 \\
\hline$z$ & 8 & ळ & in & $\bar{\sigma}$ & $\widetilde{\sigma}$ & 今ે & ஓి \\
\hline 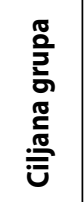 & 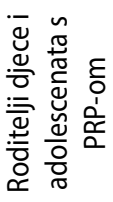 & 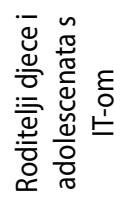 & 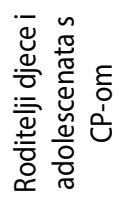 & 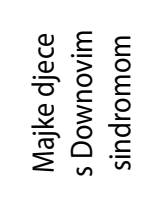 & 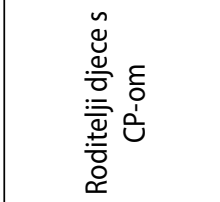 & 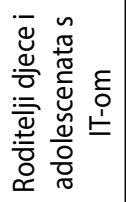 & 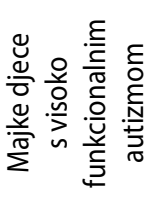 \\
\hline 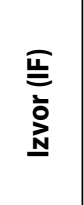 & 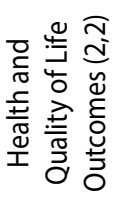 & 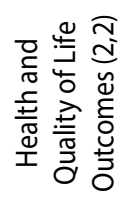 & 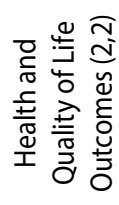 & 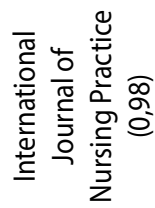 & 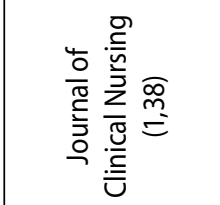 & 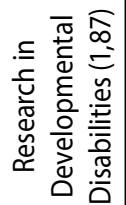 & 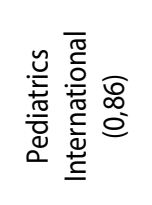 \\
\hline $\begin{array}{l}\frac{2}{0} \\
\frac{0}{3} \\
\frac{3}{2}\end{array}$ & 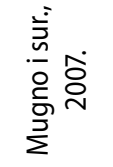 & 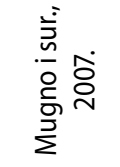 & 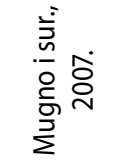 & 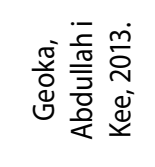 & 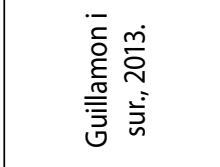 & 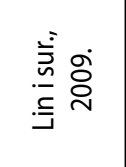 & 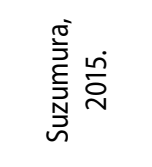 \\
\hline 六: & - & $v$ & $m$ & $\nabla$ & in & 0 & - \\
\hline
\end{tabular}


A. Bogdanović, M. Spasić Šnele: Postoji li razlika u procjeni kvalitete života između roditelja djece...

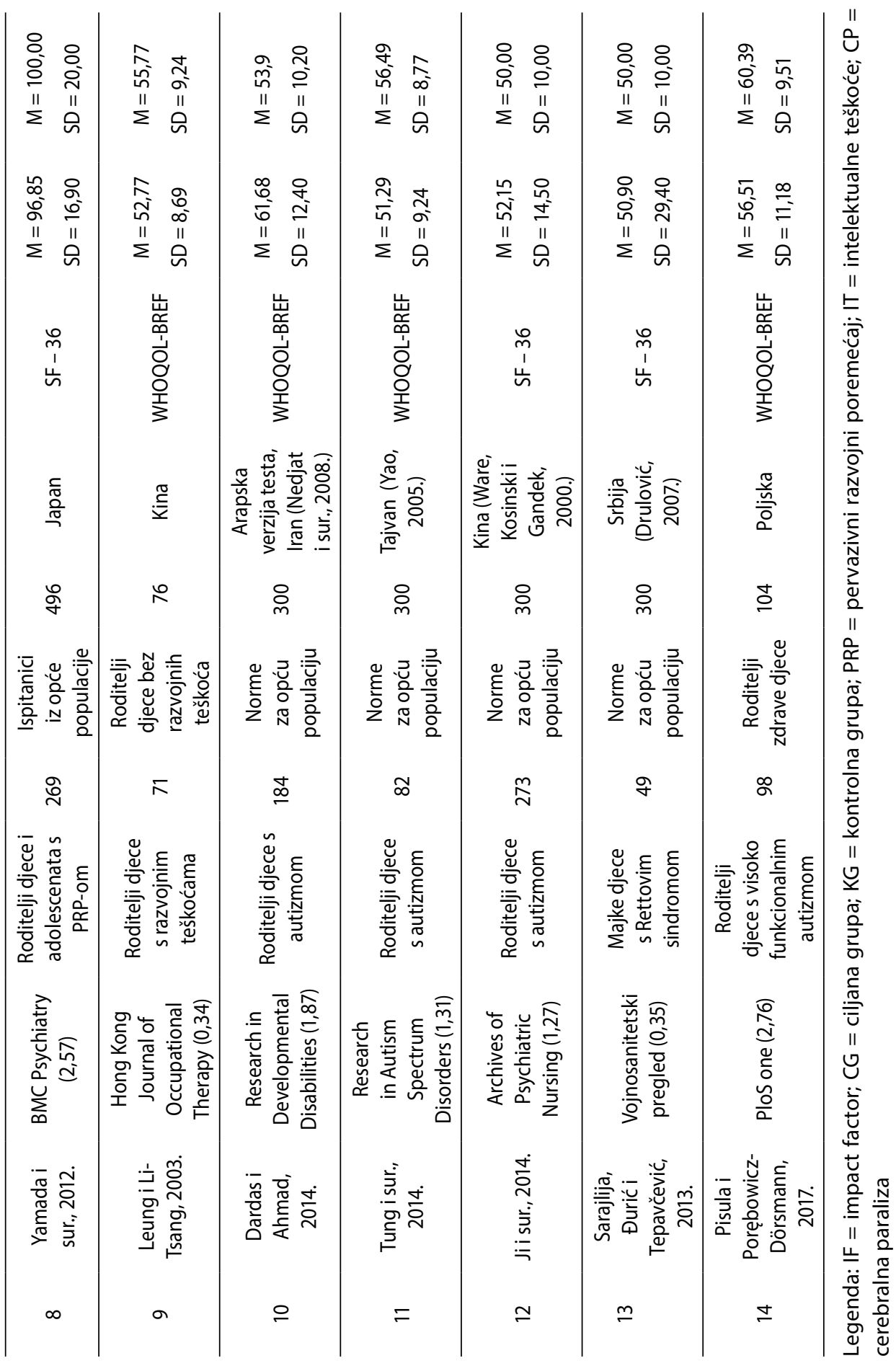


Iz Tablice 1. vidimo da sedam istraživanja nema kontrolnu grupu, već se za usporedbu koriste norme izgrađene na temelju rezultata opće populacije za određeni upitnik, za Maleziju (Skevington, Lotfy i O'Connell, 2004.), Španjolsku (Hawthorne, Herrman i Murphy, 2006.), Tajvan (Yao, 2005.), Iran (Nedjat i sur., 2008.), Kinu (Ware, Kosinski i Gandek, 2000.) i Srbiju (Drulović, 2007.). Nadalje, kako je predmet metaanalize ispitivanje veličine razlike između dvije grupe ispitanika, kao mjera veličine učinka pojedinačnih istraživanja i ukupna mjera veličine učinka korištena je standardizirana razlika između aritmetičkih sredina izražena kao Cohenov d indeks veličine učinka. U skladu s tim, za potrebe metaanalize iz navedenih istraživanja uzete su aritmetičke sredine i standardne devijacije varijabli koje su predmet interesa (Tablica 1.). Računanje pojedinačnih, kao i ukupne mjere veličine učinka, izvršeno je u okviru softvera »Comprehensive Meta-Analysis - trial version«.

Jedan od ciljeva istraživanja jest ispitati postoji li i kolika je razlika u kvaliteti života između majki i očeva djece s razvojnim teškoćama. Pregledom izdvojenih istraživanja utvrđeno je da su u sedam od predstavljenih 14 istraživanja dani podaci potrebni za računanje razlike u kvaliteti života majki i očeva (Tablica 2.).

Tablica 2. Istraživanja koja sadrže podatke za usporedbu kvalitete života očeva i majki

\begin{tabular}{|c|c|c|c|c|c|c|}
\hline $\begin{array}{l}\text { R. br. } \\
\text { studije }\end{array}$ & Autori & Izvor (IF) & $\underset{\text { N }}{\text { Majke }}$ & $\begin{array}{c}\text { Očevi } \\
\text { N }\end{array}$ & $\begin{array}{c}\text { M i SD za } \\
\text { majke }\end{array}$ & $\begin{array}{c}\text { MiSD za } \\
\text { očeve }\end{array}$ \\
\hline \multirow{2}{*}{1} & \multirow{2}{*}{$\begin{array}{l}\text { Mugno i sur., } \\
2007 .\end{array}$} & \multirow{2}{*}{$\begin{array}{l}\text { Health and Quality } \\
\text { of Life Outcomes } \\
(2,2)\end{array}$} & \multirow{2}{*}{39} & \multirow{2}{*}{30} & $M=57,00$ & $M=62,50$ \\
\hline & & & & & $S D=24,14$ & $S D=17,92$ \\
\hline \multirow{2}{*}{2} & \multirow{2}{*}{$\begin{array}{l}\text { Mugno i sur., } \\
2007 .\end{array}$} & \multirow{2}{*}{$\begin{array}{c}\text { Health and Quality } \\
\text { of Life Outcomes } \\
(2,2)\end{array}$} & \multirow{2}{*}{49} & \multirow{2}{*}{40} & $M=65,31$ & $M=69,60$ \\
\hline & & & & & $S D=21,12$ & $S D=17,88$ \\
\hline \multirow{2}{*}{3} & \multirow{2}{*}{$\begin{array}{l}\text { Mugno i sur., } \\
2007 .\end{array}$} & \multirow{2}{*}{$\begin{array}{l}\text { Health and Quality } \\
\text { of Life Outcomes } \\
(2,2)\end{array}$} & \multirow{2}{*}{42} & \multirow{2}{*}{35} & $M=62,21$ & $M=64,71$ \\
\hline & & & & & $\mathrm{SD}=19,40$ & $\mathrm{SD}=18,77$ \\
\hline \multirow{2}{*}{4} & \multirow{2}{*}{ Lin i sur., 2009.} & \multirow{2}{*}{$\begin{array}{c}\text { Research in } \\
\text { Developmental } \\
\text { Disabilities }(1,87) \\
\end{array}$} & \multirow{2}{*}{423} & \multirow{2}{*}{159} & $M=52,05$ & $M=50,86$ \\
\hline & & & & & $\mathrm{SD}=9,71$ & $\mathrm{SD}=9,71$ \\
\hline \multirow{2}{*}{5} & \multirow{2}{*}{$\begin{array}{l}\text { Yamada i sur., } \\
2012 .\end{array}$} & \multirow{2}{*}{$\begin{array}{c}\text { BMC Psychiatry } \\
(2,57)\end{array}$} & \multirow{2}{*}{147} & \multirow{2}{*}{122} & $M=46,6$ & $M=50,25$ \\
\hline & & & & & $\mathrm{SD}=9,40$ & $S D=6,75$ \\
\hline \multirow{2}{*}{6} & \multirow{2}{*}{$\begin{array}{c}\text { Dardas i Ahmad, } \\
2014 .\end{array}$} & \multirow{2}{*}{$\begin{array}{c}\text { Research in } \\
\text { Developmental } \\
\text { Disabilities }(1,87) \\
\end{array}$} & \multirow{2}{*}{114} & \multirow{2}{*}{70} & $M=60,48$ & $M=62,88$ \\
\hline & & & & & $\mathrm{SD}=12,89$ & $S D=11,98$ \\
\hline \multirow[b]{2}{*}{7} & \multirow{2}{*}{$\begin{array}{c}\text { Pisula i } \\
\text { Porębowicz- } \\
\text { Dörsmann, } 2017 .\end{array}$} & \multirow{2}{*}{ PloS one $(2,76)$} & \multirow[b]{2}{*}{49} & \multirow{2}{*}{49} & $M=55,77$ & $M=56,40$ \\
\hline & & & & & $\mathrm{SD}=11,18$ & $\mathrm{SD}=11,84$ \\
\hline
\end{tabular}

\section{0 članci}




\section{Priroda efekata}

Istraživanja pokazuju da, unatoč kulturalnim, ekonomskim i svim drugim razlikama koje postoje u različitim dijelovima svijeta, prosječna razina kvalitete života svjetske populacije varira svega $20 \%$ (Cummins, 2003.). Objektivni uvjeti života, kao što su socio-ekonomski razvoj, bruto nacionalni dohodak, stopa zaposlenosti i sl., iako samostalno nisu dobra mjera kvalitete života, svakako su važan faktor pri njegovoj procjeni. Danas se istraživači slažu da pojam kvalitete života podrazumijeva kombinaciju objektivnih i subjektivnih čimbenika (Vuletić i Misajon, 2011.). Za nas je od posebnog značaja to što se različite sredine drugačije odnose prema osobama s invaliditetom, uključujući i djecu s teškoćama u razvoju. Na kvalitetu života roditelja, na primjer, može utjecati to kako se država odnosi prema pitanjima kao što su zaštita prava, zabrana diskriminacije, školovanje ili socijalna briga o djeci s teškoćama u razvoju. Uzorci ispitanika u istraživanjima uključenim u analizu potječu iz zemalja koje se međusobno razlikuju u objektivnim uvjetima života (Italija, Malezija, Španjolska, Tajvan, Japan, Kina, Jordan, Srbija), odnosno ne pripadaju istoj populaciji, te se ne očekuje postojanje jedne jedinstvene, homogene, veličine učinka između ispitivanih varijabli, već distribucija pravih efekata, koji variraju u određenom opsegu (model slučajnih ili varijabilnih efekata). S obzirom na to da se parametri populacije razlikuju među uključenim istraživanjima, odlučili smo se za model slučajnih efekata.

\section{Efekt »ladice»}

U okviru softvera »Comprehensive Meta-Analysis« ispitano je i postojanje efekta »ladice« (eng. file-drawer effect), odnosno pristranosti istraživanja koja su ušla u metaanalizu u odnosu na istraživanja koja nisu, a koja bi mogla imati utjecaj na ukupnu mjeru veličine učinka. 


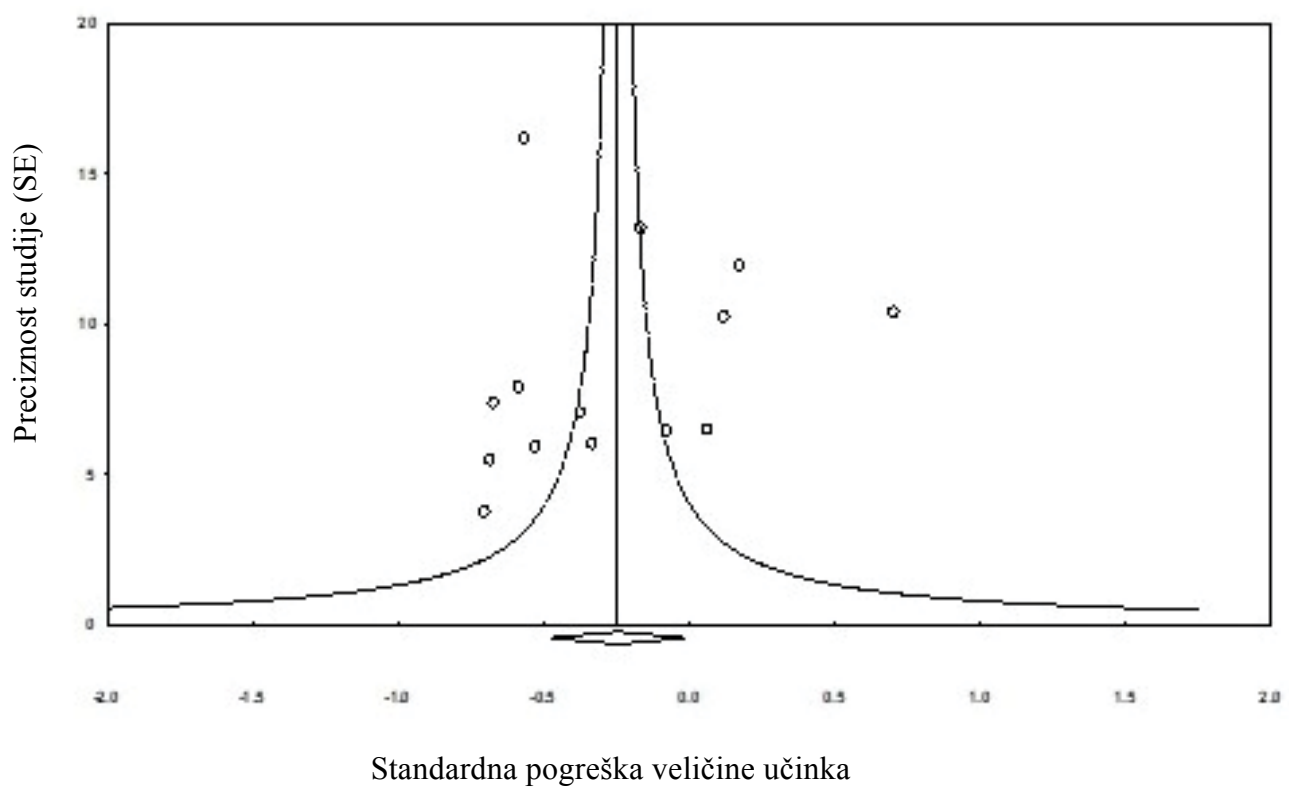

Slika 1. Grafikon lijevka (eng. funnel plot): asimetrija istraživanja koja su uključena u metaanalizu

Kao što se vidi iz Slike 1., istraživanja uključena u metaanalizu ravnomjerno su raspoređena oko vertikalne osi, što ukazuje na nepostojanje pristranosti u izboru istraživanja za metaanalizu. Trim and Fill analiza za korigiranje asimetrije ukazuje da nema istraživanja koje bi se moglo korigirati u cilju poboljšanja mjera veličine učinka u okviru modela slučajnih efekata. Rang korelacija (eng. Begg and Mazmudar's rank correlation) između standardizirane mjere ukupne veličine učinka $i$ varijance (standardne pogreške) mjere veličine učinka $(\tau=-0,16, z=0,82, p>0,05)$ nije statistički značajna, a broj potrebnih istraživanja bez rezultata koji su u skladu s nalazima ovog istraživanja da bi ukupna mjera veličine učinka postala statistički neznačajna je FSN $=144$, što također ukazuje na nepostojanje efekta »ladice« (144 $>5 * 14+10$ ) (Rosenthal, 1991.).

\section{REZULTATI}

U Tablici 3. predstavljene su veličine standardiziranih razlika između aritmetičkih sredina roditelja djece s teškoćama u razvoju i roditelja zdrave djece u pojedinačnim istraživanjima. Na osnovi dobivenih rezultata možemo uočiti da se u polovici uključenih istraživanja vrijednost Cohenovog d koeficijenta nalazi u opsegu od -0,56 do 0,70 ukazujući na umjerenu razliku u procjeni kvalitete života između

\section{2 članci}


A. Bogdanović, M. Spasić Šnele: Postoji li razlika u procjeni kvalitete života između roditelja djece...

usporednih grupa, dok je u ostalim istraživanjima veličina učinka razlike između aritmetičkih sredina mala (Cohen, 1992., prema Fajgelj, 2012.).

Tablica 3. Mjere veličine učinka u pojedinačnim istraživanjima - kvaliteta života, kompozitni rezultat

\begin{tabular}{cc}
\hline R. br. studije & Cohenov d \\
\hline 1 & $-0,52$ \\
2 & $-0,07$ \\
3 & $-0,68$ \\
4 & 0,11 \\
5 & $-0,67$ \\
6 & $-0,56$ \\
7 & $-0,70$ \\
8 & $-0,16$ \\
9 & $-0,33$ \\
10 & 0,70 \\
11 & $-0,58$ \\
12 & 0,17 \\
13 & 0,06 \\
14 & $-0,37$ \\
\hline
\end{tabular}

Iz rezultata prikazanih u Tablici 4. proizlazi da postoji statistički značajna razlika između roditelja djece s teškoćama u razvoju i roditelja djece bez teškoća u razvoju u pogledu subjektivne procjene kvalitete života, $(z=-2,06, p<0,05)$. Vrijednost standardizirane razlike između aritmetičkih sredina $(d=-0,24)$ niskog je intenziteta (Cohen, 1992., prema Fajgelj, 2012.).

Tablica 4. Metaanaliza: razlika u procjeni kvalitete života između roditelja djece s teškoćama u razvoju i roditelja zdrave djece

\begin{tabular}{ccccccc}
\hline \multicolumn{6}{c}{ Model varijabilnih efekta } \\
\hline $\begin{array}{c}\text { Broj } \\
\text { istraživanja }\end{array}$ & $\begin{array}{c}\text { Bspitanika } \\
\text { u ciljanoj } \\
\text { grupi }\end{array}$ & $\begin{array}{c}\text { Broj } \\
\text { ispitanika u } \\
\text { kontrolnoj } \\
\text { grupi }\end{array}$ & $\begin{array}{c}\text { Standardizirana } \\
\text { razlika između } \\
\text { aritmetičkih } \\
\text { sredina }\end{array}$ & $\begin{array}{c}\text { 95\% interval } \\
\text { pouzdanosti }\end{array}$ & z \\
\hline 14 & 2088 & 3489 & $-0,24$ & $-0,47--0,01$ & $-2,06^{*}$ \\
\hline
\end{tabular}

${ }^{*} p<0,05$ 
Na temelju Tablice 5. vidimo da je veličina razlike u kvaliteti života između majke i očeva djece sa smetnjama u razvoju niskog intenziteta u svim, izuzev jednog istraživanja (Yamada i sur., 2012.) ( $d=-0,44)$, u kojoj je pronađena razlika umjerenog intenziteta.

Tablica 5. Mjere veličine učinka u pojedinačnim istraživanjima u kojima se uspoređuje kvaliteta života majki i očeva djece s teškoćama u razvoju - kompozitni rezultat

\begin{tabular}{lccccccc}
\hline R. br. studije & $\mathbf{1}$ & $\mathbf{2}$ & $\mathbf{3}$ & $\mathbf{4}$ & $\mathbf{5}$ & $\mathbf{6}$ & $\mathbf{7}$ \\
\hline Cohenov d & $-0,27$ & $-0,21$ & $-0,13$ & 0,12 & $-0,44$ & $-0,19$ & $-0,05$ \\
\hline
\end{tabular}

Iz Tablice 6. uočava se da ne postoji statistički značajna razlika između majki i očeva djece s teškoćama u razvoju u pogledu subjektivne procjene kvalitete života.

Tablica 6. Razlike u procjeni kvalitete života između majki i očeva djece s teškoćama u razvoju - kompozitni rezultat

\begin{tabular}{|c|c|c|c|c|c|}
\hline \multicolumn{6}{|c|}{ Model varijabilnih efekata } \\
\hline $\begin{array}{c}\text { Broj } \\
\text { studija }\end{array}$ & $\begin{array}{l}\text { Majke } \\
\text { (N) }\end{array}$ & $\begin{array}{l}\text { Očevi } \\
\text { (N) }\end{array}$ & $\begin{array}{c}\text { Standardizirana razlika } \\
\text { između aritmetičkih sredina }\end{array}$ & $\begin{array}{l}95 \% \text { interval } \\
\text { pouzdanosti }\end{array}$ & $\mathbf{z}$ \\
\hline 7 & 863 & 505 & $-0,15$ & $-0,34-0,03$ & $-1,64$ \\
\hline
\end{tabular}

\section{RASPRAVA}

Osnovni cilj ovog rada bilo je metaanaličko proučavanje veličine razlike u subjektivnoj procjeni kvalitete života između roditelja djece s teškoćama u razvoju i roditelja djece bez teškoća u razvoju. Pored toga zanimalo nas je postoje li razlike u procjeni kvalitete života između majke i očeva djece s teškoćama u razvoju. Rezultati pokazuju da postoji statistički značajna razlika niskog intenziteta između roditelja djece $s$ teškoćama u razvoju i roditelja djece bez teškoća u razvoju u pogledu subjektivne procjene kvalitete života, pri čemu je lošija kvaliteta života roditelja djece s teškoćama u razvoju. Polazeći od definicije kvalitete života Svjetske zdravstvene organizacije, koja kvalitetu života određuje kao osobnu percepciju vlastitog načina života u kontekstu kulture, sustava vrijednosti, težnji, izgleda za budućnost, standarda i interesa (Whoqol Group, 1998.), dobiveni rezultat svakako možemo smatrati očekivanim. Naime, život s djetetom s teškoćama u razvoju predstavlja situaciju koja je u mnogome drugačija od života s djetetom bez teškoća u razvoju. Pođimo od toga da je prvi korak koji roditelji moraju učiniti odricanje od snova o »savršenom djetetu«

\section{4 članci}




\section{A. Bogdanović, M. Spasić Šnele: Postoji li razlika u procjeni kvalitete života između roditelja djece...}

(Milić Babić, 2012.). Nije rijetko da nakon saznavanja za dijagnozu djeteta, roditelji izvještavaju o reakcijama koje su vrlo slične reakcijama na gubitak bliske osobe, kao što su šok, nevjerica, kontinuirana tuga (Rajić i Mihić, 2015.). Dalje, zahtjevi koji se stavljaju pred obitelj su veći i drugačiji u odnosu na obitelj s djetetom bez teškoća u razvoju, a koji se posebno ogledaju u preuzimanju većeg dijela odgovornosti za odluke koje se tiču brige i dobrobiti djeteta (Milićević, 2015.).

Promjene se događaju i unutar obitelji. Zbog prilagodbi potrebama djeteta i zanemarivanja potreba drugih članova obitelji uobičajeno dolazi do narušavanja obiteljske kohezivnosti (Milić Babić, 2012.). Nije manje značajno spomenuti i to da roditelji često odustaju od planiranih aktivnosti, primjerice, hobija kako bi zadovoljili "posebne potrebe « djeteta (Leung i Li-Tsang, 2003.; Milić Babić, 2012.), što vjerojatno negativno utječe na njihovu kvalitetu života. Pored toga, napor koji specifične okolnosti života s djetetom koje ima teškoće u razvoju iziskuju, ponašanje djeteta, (koje često uključuje agresivna, samodestruktivna, impulzivna i samostimulativna izražavanja), ograničenosti u razvoju djetetovih socijalnih vještina, pojačan napor da se razumiju djetetove potrebe, stalni nadzor i pomaganje u svakodnevnim životnim aktivnostima, kao i briga za djetetovu budućnost utječu na mentalno zdravlje roditelja (Mugno i sur., 2007.). Dalje, strah od reakcije društva na potrebe njihovog djeteta, ali i nedostatak vremena koje bi roditelji mogli posvetiti svom socijalnom životu, zbog stalnog bavljenja djetetom (Ayrault, 2001.), doprinose njihovoj socijalnoj izolaciji, što sve skupa narušava ukupnu kvalitetu života roditelja djeteta s teškoćama u razvoju. Svakako treba imati na umu i to da kvaliteta života podrazumijeva kombinaciju objektivnih i subjektivnih čimbenika (Vuletić i Misajon, 2011.). Pojačani financijski zahtjevi, na primjer, mogu dodatno opterećivati njihovo roditeljstvo (Singer i Powers, 1993.; Leung i Li-Tsang, 2003.) i potencijalno utjecati na smanjenje kvalitete života. Imajući u vidu da bolja percepcija kvalitete života roditelja ima direktne implikacije na poboljšanje kvalitete roditeljstva (Mugno i sur., 2007., prema Tung i sur., 2014.), odnosa roditelj-dijete (Beach i sur., 2005.) i boljitak čitave obitelji (Brown i sur., 2006., prema Dardas i Lafeta, 2014.), nije na odmet naglasiti da jedan od važnih ciljeva intervencija namijenjenih obiteljima djece s teškoćama u razvoju treba biti upravo poboljšanje kvalitete života, a posebno poboljšanje mentalnog zdravlja i socijalnih interakcija roditelja djece s teškoćama u razvoju.

Kada je riječ o majkama i očevima djece s teškoćama u razvoju, mada se moglo očekivati da će postojati statistički značajna razlika u procjeni kvalitete života imajući u vidu pojedina prethodna istraživanja (Mugno i sur., 2007.), nalazi nisu potvrdili

4 Termin izveden od često korištenog, ali ne neosporavanog, naziva za imenovanje djece s teškoćama u razvoju: djeca s posebnim potrebama. Treba se prisjetiti da su djeca s posebnim potrebama prije svega djeca, ali djeca koja od najranijeg uzrasta zahtijevaju posebne - dodatne uvjete za razvoj (Hrnjica, 1997., prema Stojilković, 2013.). 
ovu pretpostavku. Subjektivna procjena kvalitete života očeva isto tako opada kao i subjektivna procjena kvalitete života majki. Otvoreno je, međutim, pitanje o sličnosti, odnosno posebnosti, faktora povezanih s kvalitetom života majke, odnosno oca djeteta s teškoćama u razvoju. Primjera radi, odnos između partnera predstavlja značajan prediktor kvalitete života majki, ali ne i očeva ove djece (Yamada i sur., 2012.). Razmatranje čimbenika koji su važni za kvalitetu jednog, odnosno drugog roditelja, kao važan zadatak u budućnosti, imalo bi poseban značaj u formiranju i provođenju usmjerenih intervencija, koje bi, prilagođenije potrebama pojedinaca, svakako imale veću efikasnost.

Treba biti svjestan ograničenja koja su proizašla iz metodologije ovog istraživanja: do uzorka koji je brojao 14 istraživanja objavljenih u najutjecajnijim svjetskim časopisima doveli su nas prethodno definirani uključujući i isključujući kriteriji. lako analiza pokazuje da nije bilo pristranosti pri izboru istraživanja, treba imati na umu da su isključena sva istraživanja objavljena na jezicima drugačijim od engleskog $i$ srpsko-hrvatsko-bosanskog, kao i istraživanja koja su objavljivana u znanstvenim publikacijama koje nisu znanstveni časopisi. Istraživanja uključena u postupak metaanalize razlikovala su se u pristupu mjerenja kvalitete života; devet istraživanja koristilo je »WHOQOL-BREF« (Whoqol Group, 1998.), skraćenu formu upitnika Svjetske zdravstvene organizacije, a preostalih četiri "SF-36«, Warea, Kosinskog i Gandeka (2000.), iza kojih leži slična definicija kvalitete života, koja podrazumijeva multidimenzionalni karakter fenomena, sa slično definiranim dimenzijama. Za potrebe ovog rada mi smo rezultate s pojedinačnih ili kompozitnih dimenzija svodili na jedan ukupni rezultat, računanjem aritmetičke sredine, te je kvantitativno proučavan samo ukupan rezultat na testovima, uz preglednu analizu rezultata na subdimenzijama. Mišljenja smo da bi kvantitativno proučavanje dimenzija kvalitete života, uz poseban naglasak na dimenzije mentalno zdravlje i socijalne interakcije, moglo dati potpuniju sliku, te je ovo preporuka za buduće istraživače. Nadalje, većina razmatranih istraživanja uključuje veći broj majki nego očeva, dok su tri istraživanja potpuno isključila očeve iz uzorka (Geoka, Abdullah i Kee, 2013.; Sarajlija, Đurić i Tepavčević, 2013.; Suzumura, 2015.). Sljedeća istraživanja trebala bi u većoj mjeri uključiti očeve djece s teškoćama u razvoju, posebno kada se ima na umu činjenica da su rezultati usporedbe majki i očeva u dva istraživanja koja smo mi analizirali (Mugno i sur., 2007.; Dardas i Ahmad, 2014.) neusuglašeni. Također, u pojedinim istraživanjima (Yamada i sur., 2012.) pokazalo se da bake i djedovi imaju značajnu ulogu u očuvanju kvalitete života roditelja, prije svega majke, ukazujući na potrebu za proširenjem fokusa pažnje i na ostale članove šire i uže obitelji. Pored toga, u pojedinim istraživanjima prepoznat je značaj i nekih drugih varijabli za kvalitetu života roditelja djece s teškoćama u razvoju, kao što su život u gradu/selu, zaposlenost, stupanj obrazovanja majke (Geoka, Abdullah i Kee, 2013.), starost majke

\section{6 članci}




\section{A. Bogdanović, M. Spasić Šnele: Postoji li razlika u procjeni kvalitete života između roditelja djece...}

(Geoka, Abdullah i Kee, 2013.; Sarajlija, Đurić i Tepavčević, 2013.), prihodi obitelji (Lin i sur., 2009.; Dardas i Ahmad, 2014.), prisustvo braće i sestara (Dardas i Ahmad, 2014.). Imajući na umu njihov potencijalni značaj, smatramo da bi trebali imati posebno mjesto u budućim istraživanjima iz ovog područja.

\section{ZAKLJUČAK}

Rezultati provedenog metaanalitičkog istraživanja ukazuju na to da je kvaliteta života roditelja djece s teškoćama u razvoju lošija u odnosu na roditelje djece bez teškoća u razvoju. Imajući na umu da niska kvaliteta života roditelja može imati direktan negativan učinak na djecu s teškoćama u razvoju, njihovu braću i/ili sestre, kao i na čitavu obitelj mišljenja smo da je pri izradi planova i strategija za pomoć, brigu i unaprjeđenje položaja djece s teškoćama u razvoju i njihovih obitelji važno uzeti u obzir i ovaj faktor. Štoviše, poboljšanje kvalitete života, posebno poboljšanje mentalnog zdravlja i socijalnih interakcija roditelja trebalo bi biti jedan od ključnih ciljeva intervencija namijenjenih obiteljima djece s teškoćama u razvoju. Dalje aktivnosti treba usmjeriti na prepoznavanje čimbenika koji su od značaja za kvalitetu života roditelja putem kvalitativnih i kvantitativnih istraživanja, na osnovi čijih rezultata bi bili osmišljeni modeli pomoći roditeljima koji bi djelovali ne samo kroz instrumentalnu pomoć obitelji, već i na razini mentalnog zdravlja, ali i šireg socijalnog okruženja.

\section{LITERATURA}

1. Ayrault, E. W. (2001). Beyond a physical disability. The person qithin: A practical guide. New York: The Continuum International Publishing Group.

2. Beach, S. R., Schulz, R., Williamson, G. M., Miller, L. S., Weiner, M. F. \& Lance, C. E. (2005). Risk factors for potentially harmful informal caregiver behavior. Journal of the American Geriatrics Society, 53 (2), 255-261. https://doi.org/10.1111/j.15325415.2005.53111.x

3. Blacher, J. (1984). Severely handicapped young children and their families research in review. Orlando: Academic Press.

4. Cummins, R. A. (2000). Objective and subjective quality of life: An interactive model. Social Indicator Research, 52 (1), 55-72.

5. Cummins, R. A. (2003). Normative life satisfaction: Measurement issues and a homeostatic model. Social Indicator Research, 64 (2), 225-256.

6. Dardas, L. \& Ahmad, M. (2014). Quality of life among parents of children with autistic disorder: A sample from the Arab world. Research in Developmental Disabilities, 35 (2), 278-287. https://doi.org/10.1016/j.ridd.2013.10.029 
7. Drulović, J., Pekmezović, T., Matejić B., Mesaroš, S., Manigoda, M. \& Dujmović, I. (2007). Quality of life in patients with multiple sclerosis in Serbia. Acta Neurologica Scandinavica, 115 (3), 147-152. https://doi.org/10.1111/j.1600-0404.2006.00729.x

8. Dulčić, A. (2001). Neki aspekti života s djetetom sa smetnjama u razvoju. Dijete idruštvo, 3, 251-260.

9. Emerson, E. (2003). Mothers of children and adolescents with intellectual disability: Social and economic situation, mental health status, and the self-assessed social and psychological impact of the child's difficulties. Journal of Intellectual Disability Research, 47, 385-399. https://doi.org/10.1046/j.1365-2788.2003.00498.x

10. Fajgelj, S. (2012). Metode istraživanja ponašanja (V. dopunjeno izdanje). Beograd: Centar za primenjenu psihologiju.

11. Geok, C. K., Abdullah, K. L. \& Kee, L. H. (2013). Quality of life among Malaysian mothers with a child with Down syndrome. International Journal of Nrsing Practice, 19 (4), 381-389. https://doi.org/10.1111/ijn.12083

12. Guillamón, N., Nieto, R., Pousada, M., Redolar, D., Muñoz, E., Hernández, E. \& Gómez-Zúñiga, B. (2013). Quality of life and mental health among parents of children with cerebral palsy: The influence of self-efficacy and coping strategies. Journal of Clinical Nursing, 22 (11-12), 1579-1590. https://doi.org/10.1111/jocn.12124

13. Hawthorne, G., Herrman, H. \& Murphy, B. (2006). Interpreting the WHOQOLBref: preliminary population norms and effect sizes. Social Indicators Research, 77, 37-59.

14. Hedov, G., Anneren, G. \& Wikblad, K. (2000). Self-perceived health in Swedish parents of children with Down's syndrome. Quality of Life Research, 9, 415-422.

15. Holroyd, J., Brown, N., Wikler, L. \& Simmons, J. Q. (1975). Stress in families of institutionalized and noninstitutionalized autistic children. Journal of Community Psychology, 3, 26-31.

16. Ilić, I., Milić, I. \& Aranđelović, M. (2010). Assessing quality of life: Current approaches. Acta medica Medianae, 49 (4), 52-60.

17. Ji, B., Zhao, I., Turner, C., Sun, M., Yi, R. \& Tang, S. (2014). Predictors of health-related quality of life in Chinese caregivers of children with autism spectrum disorders: A cross-sectional study. Archives of Psychiatric Nursing, 28 (5), 327-332. https:// doi.org/10.1016/j.apnu.2014.06.001

18. Krizmanić, M. \& Kolesarić, V. (1989). Pokušaj konceptualizacije pojma »kvalitet života«. Primenjena psihologija, 10, 179-184.

19. Leung, C. \& Li-Tsang, C. (2003). Quality of life of parents who have children with disabilities. Hong Kong Journal of Occupational Therapy, 13 (1), 19-24.

20. Leutar, Z. \& Rajić, I. (2002). Dijete s mentalnom retardacijom u obitelji. Ljetopis studijskog centra socijalnog rada, 9 (1), 29-47.

21. Lin, J. D., Hu, J., Yen, C. F., Hsu, S. W., Lin, L. P., Loh, C. H., Chen, M. H., Wu, S. R., Chu, C. M. \& Wu, J. L. (2009). Quality of life in caregivers of children and adolescents

\section{8 članci}


with intellectual disabilities: Use of WHOQOL-BREF survey. Research in Developmental Disabilities, 30 (6), 1448-1458. https://doi.org/10.1016/j.ridd.2009.07.005

22. Milić Babić, M. (2012). Obiteljska kohezivnost u obiteljima djece s teškoćama u razvoju. Nova prisutnost: časopis za intelektualna iduhovna pitanja, 10 (2), 207-223.

23. Milićević, M. (2015). Kvalitet života porodica sa detetom sa ometenošću. Beogradska defektološka škola, 21 (2), 39-46.

24. Mugno, D., Ruta, L., D’Arrigo, V. G. \& Mazzone, L. (2007). Impairment of quality of life in parents of children and adolescents with pervasive developmental disorder. Health and Quality of Life Outcomes, 5 (1), 1. https://doi.org/10.1186/14777525-5-22

25. Nedjat, S., Montazeri, A., Holakouie, K., Mohammad, K. \& Majdzadeh, R. (2008). Psychometric properties of the Iranian interview-administered version of the World Health Organization's Quality of Life Questionnaire (WHOQOL-BREF): A population-based study. BMC Health Services Research, 8, 61. https://doi. org/10.1186/1472-6963-8-61

26. Pisula, E. \& Porębowicz-Dörsmann, A. (2017). Family functioning, parenting stress and quality of life in mothers and fathers of Polish children with high functioning autism or Asperger syndrome. PloS one, 12 (10), e0186536. https:// doi.org/10.1371/journal.pone.0186536

27. Rajić, M. \& Mihić, I. (2015). Socioemocionalna posvećenost roditelja dece sa smetnjama u razvoju: razlike između majki i očeva. Годишњак Филозофског факултета у Новом Саду [Godišnjak Filozofskog fakulteta u Novom Sadu], 40 (2), 137-152.

28. Rosenthal, R. (1991). Meta-analysis: A review. Psychosomatic Medicine, 53 (3), 247-271.

29. Sarajlija, A., Đurić, M. \& Kisić-Tepavčević, D. (2013). Health-related quality of life and depression in Rett syndrome caregivers. Vojnosanitetski pregled, 70 (9), 842847.

30. Schalock, R. L. (2004). The concept of quality of life: What we know and do not know. Journal of Intellectual Disabily Research, 48 (3), 203-216.

31. Schieve, L. A., Blumberg, S. J., Rice, C., Visser, S. N. \& Boyle, C. (2007). The relationship between autism and parenting stress. Pediatrics, 119 (1), 114-121.

32. Silva, L. M. \& Schalock, M. (2012). Autism parenting stress index: Initial psychometric evidence. Journal of Autism and Developmental Disorders, 42 (4), 566-574. https://doi.org/10.1007/s10803-011-1274-1

33. Singer, G. H. \& Powers, L. E. (1993). Contributing to resilience in families: An overview. In: Singer, George, H. \& Powers, Laurie, E. (eds.), Families, disability, and empowerment: Active coping skills and strategies for family interventions. Baltimore: Paul H. Brookes Publishing, 1-25. 
34. Skevington, S. M., Lotfy, M. \& O'Connell, K. A. (2004). The World Health Organization's WHOQOL-BREF quality of life assessment: Psychometric properties and results of the international field trial A Report from the WHOQOL Group. Quality of Life Research, 13, 299-310.

35. Stojilković, A. (2013). Empatija, anksioznost i samopoštovanje kod braće/sestara mentalno nedovoljno razvijenih osoba. Magistarski rad. Niš: Filozofski fakultet.

36. Suzumura, S. (2015). Quality of life in mothers of preschoolers with high-functioning pervasive developmental disorders. Pediatrics International, 57, 149-154. https://doi.org/10.1111/ped.12560

37. Tsuno, N., Besset, A. \& Ritchie, K. (2005). Sleep and depression. Journal of Clinical Psychiatry, 66 (10), 1254-1269. https://doi.org/10.4088/JCP.v66n1008.

38. Tung, L. C., Huang, C. Y., Tseng, M. H., Yen, H. C., Tsai, J. P., Lin, Y. C. \& Chen, L. P. (2014). Correlates of health-related quality of life and the perception of its importance in caregivers of children with autism. Research in Autism Spectrum Disorders, 8 (9), 1235-1242. https://doi.org/10.1016/j.rasd.2014.06.010

39. van Zelst, B., Miller, M., Russo, R., Murchland, S. \& Crotty, M. (2006). Activities of daily living in children with hemiplegic cerebral palsy: A cross-sectional evaluation using the Assessment of Motor and Process Skills. Developmental Medicine \& Child Neurology, 48 (9), 723-727. https://doi.org/10.1017/S0012162206001551. PMID 16904017

40. Vasilopoulou, E. \& Nisbet, J. (2016). The quality of life of parents of children with autism spectrum disorder: A systematic review. Research in Autism Spectrum Disorders, 23, 36-49. https://doi.org/10.1016/j.rasd.2015.11.008

41. Vuletić, G. \& Misajon, R. (2011). Subjektivna kvaliteta života: povijesni pregled. U: G. Vuletić (ur.), Kvaliteta života i zdravlje. Osijek: Filozofski fakultet, 9-16.

42. Ware, J. E., Kosinski, M. \& Gandek, B. (2000). SF-36 Health Survey: Manual and Interpretation Guide. Lincoln, RI: QualityMetric Incorporatd.

43. Weiss, S. J. (1991). Stressors experienced by family caregivers of children with pervasive developmental disorders. Child Psychiatry and Human Development, 21, 203-216.

44. Whoqol Group (1998). Development of the World Health Organization WHOQOLBREF quality of life assessment. Psychological Medicine, 28 (3), 551-558.

45. Yamada, A., Kato, M., Suzuki, M., Suzuki, M., Watanabe, N., Akechi, T. \& Furukawa, T. A. (2012). Quality of life of parents raising children with pervasive developmental disorders. BMC Psychiatry, 12 (1), 1. https://doi.org/10.1186/1471-244X-12-119

46. Yao, K. P. (2005). Development of the WHOQOL-BREF-Taiwan version-user guide, 2nd version. Taipei: WHOQOL-BREF-Taiwan Version Study Group.

\section{0 članci}


A. Bogdanović, M. Spasić Šnele: Postoji li razlika u procjeni kvalitete života između roditelja djece...

Aleksandra Bogdanović

Miljana Spasić Šnele

University of Niš

Faculty of Philosophy

\section{IS THERE A DIFFERENCE IN THE QUALITY OF LIFE ASSESSMENT BETWEEN PARENTS OF CHILDREN WITH DEVELOPMENTAL DISABILITIES AND PARENTS OF CHILDREN WITHOUT DEVELOPMENTAL DISABILITIES: A META-ANALYSIS}

\section{ABSTRACT}

This meta-analysis was conducted with the aim of integrating the results of individual studies concerning differences in subjective quality of life assessment of parents of children with developmental disabilities and parents of children without developmental disabilities or the general population. The meta-analysis was conducted on a sample of 14 individual studies and covered 2088 parents of children with developmental disabilities and 783 parents of children without disabilities across seven studies, while the remaining seven studies were compared against standards based on results for the population without disabilities for a given geographical area. The standardized difference score between arithmetic means is $d=0.24$ and points to a statistically significant difference of low intensity between parents of children with developmental disabilities and parents of children without developmental disabilities or population without disabilities in terms of the subjective quality of life assessment $(z=-2.06, p=0.039)$ with the quality of life rated lower by parents of children with developmental disabilities. Within the group of parents of children with developmental disabilities no difference in the quality of life assessment was established between mothers and fathers.

The results of the study indicate the need for developing better and more focused interventions aimed at providing support and assistance to this group. However, it should be kept in mind that this study has methodology-related limitations and future researchers are therefore advised to address the shortcomings of this study in order to improve the quality and validity of results.

Key words: quality of life, parents, parents of children with developmental disabilities.

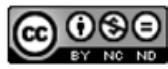

Međunarodna licenca / International License:

Creative Commons Attribution-NonCommercial-NoDerivatives 4.0. 
